\title{
THE IMPACT OF CULTURE ON INTERNATIONAL MANAGEMENT: A SURVEY OF PROJ ECT COMMUNICATIONS IN SINGAPORE
}

\author{
Duc Tran and Professor Martin Skitmore \\ Queensland University of Technology
}

\section{INTRODUCTION}

Right across industry, the attitude of senior management to their corporate affairs is evolving in response to the globalisation of business, the spread of information technologies, the growth of shareholder activism and increased intrusiveness of international and national governments in key areas of business management. A misfit of cultures is often a cause of failure (Cartwright and Cooper, 1996; Cartwright and Cooper, 1993; Olie, 1994). In particular, managers' strong preference for culturally similar environments has been identified as a major problem (Oudenhoven and De Boer, 1995). A major challenge of doing business internationally is clearly to adapt effectively to different cultures. Such adaptation requires an understanding of cultural diversity, perception and values (Granell, 2000).

In Australia, historically high levels of protection, particularly in the form of tariffs, have been the mainstay of Australian industry policy (Buxey, 2000). The consequence of this protectionism has been an inwardlooking industry with a low level of competitiveness in international markets. For many corporations in the 1990s, the highest priority was to develop an Asian focus-the socalled Asian Challenge. However, international knowledge in Australia is biased in favour of Europe and there has been slow progress in developing significant and meaningful changes in attitudes, knowledge and awareness of Asian ways (Edwards et al., 1997). The tendency to date has been to take those management concepts and techniques that worked at home into other countries and cultures. It is now apparent, both from practice and cross-cultural research, that a single, universal style of management, at least across cultures, is not tenable (Adler, 1997).

One of the most important skills for project managers in the international marketplace is that of effective communication (Harris and Kumra, 2000). Communication takes on special important in cross-culture management because of the difficulties in conveying meanings between parties from different cultures. The problems of misinterpretation and error are compounded in the international context. To overcome this, cross-cultural managers have to adapt and be flexible in the new environment; in addition to having the required functional and survival skills. Thus, cross-cultural managers require an understanding of the meanings and dimensions of culture, organizational culture and diversity, and intercultural communication.

With intensified internationalisation of business, there has been a notable increase of research interest in the relationship between national culture, values and managerial orientations and behaviour. The more recent work by Hall and Hall (1994a), Trompenaars and Hampden-Turner (1998b), Hofstede (1991) and Laurent (1983) explicitly links broad cultural value dimensions to management issues. Apart from Loosemore and MusImani's (1999) work in the Persian Gulf region, however, little has been done to date to document the inter-cultural communication issues in construction project management. To rectify this situation, in the Australian context, the research described in this paper aimed to explore the impact of national culture, organizational culture and inter-cultural communication on the management of a company by means of a small empirical study of the correlation between the culture diversity and intercultural communication and its barriers. This involved a questionnaire survey derived from synthesis of culture dimensions from Trompenaars and Hampden-Turner (1998b), Hofstede (1980; 1991) and Schein (1992). These dimensions enable us to describe and compare critical manifestations of organizational and national culture.

DATA

\section{Questionnaire}

The questionnaire was divided into three sections, comprising background information, with questions concerning nationality, 
employment status, field of profession and years of experience; culture, with questions relating to aspects of national culture, organisational culture and personal characteristics; and communications, with questions relating to communications in general, in projects and barriers to communication. Following Hofstede (1991), the aspects of national culture elicited were, on a five-point scale, the degree of uncertainty avoidance, individualism/collectivism, power distance and masculinity/feminity. Similarly, the aspects of organisational culture elicited were external/internal emphasis, task/ social focus, individuality/conformity, risk/safety and adhockery/planning. Personal characteristics concerned introversion/extroversion, sensing/intuition, thinking/ feeling and judging/perceiving.

\section{Research population sample}

Singapore was chosen for the survey as:

- It has a high power distance/low individualism culture, in contrast with the position of most western nations (Hofstede, 1980).

- It is a region known for its cultural diversity.

- The high English literacy rates among Singaporean managers enable a survey to be conducted in English, avoiding possible interpretation problems associated with the translation of questionnaires into other languages (Chow et al., 1991).

The targeted research sample consisted, variously, of project managers, construction managers, consultants and architects. Both local and foreign respondents within Singapore were targeted. A hundred questionnaires were forwarded to individual professionals currently working in the Singapore construction industry. Strict anonymity was observed.

\section{Response rate}

Thirty-nine responses were received. The respondents are from geographically and culturally diverse backgrounds, with a diversity of management experience, and with an average of 9 years of cross-cultural experience per respondent (Table 1). There are a variety of nationalities involved, with two major response groups being Australian (23\%) and Singaporean (22\%). The majority are project managers, with $85 \%$ having five or more years of experience in the construction industry.

\section{RESULTS}

Respondents were allocated into Far Eastern (46\%) and Anglo (54\%) groups (after Ronen and Shenkar, 1985). Sample correlation coefficients were then computed between the cultural variables (National, Organisational and Personal Characteristics) and communication variables (Communication in General, Project Based Communications and Barriers) for Pooled Data, Anglo Clusterand Far Eastern Cluster.

\section{Effects of cultural factors on}

\section{communication}

As Hall (1959) has noted, many intercultural communication difficulties stem from the lack of knowledge of how to communicate with people in other countries. Behaviours and orientations considered appropriate in one culture can be offensive to people from another culture. Obtaining knowledge about the communicative styles and orientations of persons in other cultures should help to reduce this happening inadvertently, as well as the misinterpretation of communication behaviours and orientations of people from other cultures. It is important, therefore, to examine, interculturally, those factors that have been found to have a significant $(p<0.05)$ influence on communication behaviours. In focusing on these, the results are presented for the three dimensions in the questionnaire-National, Organisational and Personal.

\section{National Culture}

The correlation between "Uncertainty Avoidance" and the general "Communication to the external of the organisation is vital" (Table 2 ) is positive ( $r=0.41)$, which may reflect relatively low uncertainty-avoidance cultures encouraging their personnel to use their own initiative and assume responsibility for their actions. On the other hand, the correlation between "Uncertainty Avoidance" and the communication barrier "Lack of trust" is negative $(r=0.32)$, reflecting that relatively low uncertainty-avoidance cultures, being founded on trusting relationships, suffer the most when their trust is misplaced. Relatively higher uncertaintyavoidance cultures, however, where lack of trust is endemic, require more formal ways of communication, e.g., writing, in anticipation of possible future litigation. 
The correlation between "Individualism/Collectivism" and the project variable "Effective communication" is positive, indicating that the more collectivist cultures perceive effective communication to be more important than those more individualistically inclined. Certainly, in collectivist cultures, people tend to take time for consulting with, and gaining consent of, their group members. Clearly then this suggests that people from cultures with high individualism, and therefore with lesser regard or ability for effective communication, are likely to experience difficulties in communicating with those from collectivist cultures.

Table 1: Characteristics of the respondents

\begin{tabular}{|c|c|c|c|c|}
\hline \multirow{3}{*}{ Respondent } & \multicolumn{4}{|l|}{ Characteristics } \\
\hline & Q1 & Q2 & Q3 & Q4 \\
\hline & Nationality & Status & Field of Professions & Yrs. Exp. \\
\hline 1 & Singaporean & Local & Construction Manager & 15 \\
\hline 2 & Singaporean & Local & Developer & 4 \\
\hline 3 & Singaporean & Local & Project Manager & 11 \\
\hline 4 & American & Expatriate & Country Manager & 10 \\
\hline 5 & Singaporean & Local & Project Manager & 7 \\
\hline 6 & Australian & Local & Architect & 7 \\
\hline 7 & Australian/Vietnamese & Local & Construction Manager & 14 \\
\hline 8 & Singaporean & Local & Developer & 10 \\
\hline 9 & Australian & Expatriate & Consultant & 11 \\
\hline 10 & Australian & Expatriate & Project Manager & 9 \\
\hline 11 & Australian & Local & Construction Manager & 10 \\
\hline 12 & Indonesian & Expatriate & Project Manager & 2 \\
\hline 13 & Australian & Expatriate & Project Manager & 10 \\
\hline 14 & American & Expatriate & Project Manager & 15 \\
\hline 15 & Vietnamese & Local & Project Manager & 6 \\
\hline 16 & Korean & Expatriate & Architect & 2 \\
\hline 17 & British & Expatriate & Construction Manager & 10 \\
\hline 18 & American & Local & Consultant & 23 \\
\hline 19 & Singaporean & Local & Construction Manager & 5 \\
\hline 20 & Vietnamese & Local & Project Manager & 7 \\
\hline 21 & Vietnamese & Expatriate & Developer & 9 \\
\hline 22 & Australian/Vietnamese & Local & Project Manager & 16 \\
\hline 23 & British & Expatriate & Architect & 7 \\
\hline 24 & Singaporean & Local & Project Manager & 8 \\
\hline 25 & Singaporean & Local & Project Manager & 6 \\
\hline 26 & Malaysian & Local & Consultant & 8 \\
\hline 27 & Australian & Local & Consultant & 13 \\
\hline 28 & Vietnamese & Local & Project Manager & 10 \\
\hline 29 & Australian & Local & Consultant & 13 \\
\hline 30 & Australian/Vietnamese & Local & Architect & 4 \\
\hline 31 & Vietnamese & Expatriate & Project Manager & 7 \\
\hline 32 & American/Vietnamese & Expatriate & Developer & 19 \\
\hline 33 & Australian & Expatriate & Consultant & 8 \\
\hline 34 & Australian & Local & Project Manager & 4 \\
\hline 35 & American/Vietnamese & Expatriate & Construction Manager & 14 \\
\hline 36 & Bulgarian & Expatriate & Project Manager & 4 \\
\hline 37 & Malaysian & Local & Architect & 15 \\
\hline 38 & American & Expatriate & Project Manager & 5 \\
\hline 39 & Singaporean & Local & Project Manager & 6 \\
\hline
\end{tabular}


Table 2: Correlations between National Cultures and Communication variables

\begin{tabular}{|l|l|l|}
\hline Item & $\mathrm{r}$ & Communication \\
\hline \multirow{2}{*}{$\begin{array}{l}\text { Uncertainty } \\
\text { Avoidance }\end{array}$} & $+0.41^{* *}$ & $\begin{array}{l}\text { "Communication to the external of the } \\
\text { organization is vital" }\end{array}$ \\
\cline { 2 - 3 } & $+0.32^{*}$ & "Lack of trust" \\
\hline \multirow{2}{*}{$\begin{array}{l}\text { Individualism/ } \\
\text { Collectivism }\end{array}$} & $+0.33^{*}$ & "Effective communication" \\
\cline { 2 - 3 } & $-0.32^{*}$ & "Information filtering" \\
\cline { 2 - 3 } & $-0.32^{*}$ & "Lack of personal skills" \\
\hline Power distance & - & - \\
\hline $\begin{array}{l}\text { Masculinity/ } \\
\text { Femininity }\end{array}$ & $+0.40^{*}$ & "Limited resources" \\
\hline
\end{tabular}

** $p<0.01$ (2-tailed) * $p<0.05$ (2-tailed)

The correlation between "IndividualismCollectivism" and the communication barrier "Information filtering" is negative. Hall and Hall (1994b) noted that, in high-context (collectivist) societies, messages are often highly coded and implicit. As a result, the sender's job is to interpret what messages mean by correctly filtering through what is being said and the way in which the message is being conveyed. Thus, collectivists see information filtering as less of a communication barrier than individualists. Countries with relatively high-individualism also tend to have greater support for the protestant work ethic and greater individual initiative. Thus, they agreed that personal skills affect communication process. This is shown through the negatively correlated "Individualism/Collectivism" and the communication barrier "Lack of personal skills" $(r=0.32)$.

Unexpectedly, "Power Distance" was not significantly correlated with any of the communication variables. However, a positive correlation was found between "MasCulinity-Feminity" and the communication barrier "limited resources" providing some support for Hofstede's (1980) assertion that individuals in countries with a relatively high masculinity index tend to dominate with power, as resources are not likely to be beyond their control.

Organisational Culture

Frequently the question arises concerning whose cultural customs, mores and practices should take precedence in international operations. The "you attitude" principle shows that successful communication must necessarily be cation must necessarily be approached from the viewpoints of receivers, not senders (Sprinks and Wells, 1994, pp. 302-9). The results show that organisations with a relatively high external orientation need to have managers with sufficient inter, and intra, personal skills and an organisational communication strategy, but with a less flexible form and style of communication than those organisations with a relatively high internal orientation (Table 3). It is difficult to suggest reasons why the latter should be the case except that, when it comes to communicating to a particular culture, the form and style of the communication have to be permanently adapted to the cultural customs and practices of the partners.

For organisations that are relatively more social than task oriented, there appears to be a higher awareness of cultural problems and solutions, with the project variables of "High levels interpersonal/intra-personal skill management", "Understanding and appreciation of cultural difference involved", "Effective communication", "Awareness of national culture" and barrier of "Resistance to change" all having significant positive correlations.

Unexpectedly, no significant correlations were found between individuality-conformity and communication of the organisation. This contrasts with the literature on the topic, which suggests that a conformity organisation culture would have policies and procedures to control communication of the company. 
Table 3: Correlations between Organization Cultures and Communication

\begin{tabular}{|l|l|l|}
\hline Item & $r$ & Communication \\
\hline \multirow{2}{*}{$\begin{array}{l}\text { Uncertainty } \\
\text { Avoidance }\end{array}$} & $+0.41^{* *}$ & "Communication to the external of the organization \\
is vital"
\end{tabular}

A safety-conscious response to risks is expected to result in an emphasis on written, as opposed to verbal, communication. Similarly, a risk-taking culture is likely to have a higher tolerance of ambiguity than a safetyconscious culture. These relationships are manifested through a positive correlation of safety consciousness with the barrier "language difficulties". A risk-taking culture, on the other hand, perceives lack of "personal skills"as a communication barrier.

Finally, a planning culture is expected to emphasise the need for structure and a non-ambiguous communication process, while an "adhockery" culture is likely to be somewhat informally structured and less task-driven. This is justified by the findings, which show those from a planning culture to perceive a "well established organisational culture and objectives" and "communication planning," allow "effective communication" in the organisation's projects. Also, it seems understandable that different communication activities take place among people of different cultures. Thus, one way for managers to improve intercultural project communication is through knowledge of local customs and practices, which emerged through the positive correlations of "Awareness of national culture", "Understanding and appreciation of cultural difference involved" and "Understanding of language and cultural practices of local area". The surprising result was the positive correlation between "Adhockery-planning" and the communication barrier "face" although it is clear from these results that the more planning oriented organisational cultures are, as the socially oriented organisations mentioned above, somewhat more enlightened over cultural communication problems and solutions. Of course, "face" is very important from the Asian perspective, where the achievement of harmony in communication requires the maintenance of an individual's "face".

\section{Personal Characteristics}

Research in social psychology suggests that personality dimensions significantly affect the effectiveness and outcome of communication (Padgett and Wolosin, 1980; Runkel, 1956). Individual personality exerts a significant influence on both the content and style of the interactions with other parties. Extroverts, for example, are expected to prefer an interaction-oriented style of communication, involving the establishment of a personal bond with their counterparts. Introverts, on the other hand, are likely to be territorially and internally oriented. This emerged strongly through the correlations of the project variables "Two way communication both upward and downward", "Project managers with excellent communication skills", "Understanding of language and cultural practices of local area", and "Effective communication" (Table 4). Extrovert managers would seem to be more competent in both communication and the cultural practices of their working environment. Sensing types show a preference for facts and detail while intuitive types prefer innovation and focus on the big picture. This explains the correlation between "Sensing versus intuitive" and the project variable "Understanding and appreciation of cultural differences involved". The sensing person would have to explore the cultural differences involved to enhance their communication process in the project. 
Table 4: Correlation between Personal Characteristics and Communication

\begin{tabular}{|c|c|c|}
\hline Item & r & Communication \\
\hline \multirow{4}{*}{$\begin{array}{l}\text { Introversion } \\
\text { vs. } \\
\text { Extroversion }\end{array}$} & $+0.50(* *)$ & "Two way communication both upward and downward" \\
\hline & $+0.50(* *)$ & "Project managers with excellent communication skills" \\
\hline & $+0.43(* *)$ & $\begin{array}{l}\text { "Understanding of language and cultural practices of } \\
\text { local area" }\end{array}$ \\
\hline & $+0.43(* *)$ & "Effective communication" \\
\hline $\begin{array}{l}\text { Sensing vs. } \\
\text { Intuition }\end{array}$ & $-0.42(* *)$ & $\begin{array}{l}\text { "Understanding and appreciation of cultural difference } \\
\text { involved" }\end{array}$ \\
\hline \multirow{4}{*}{$\begin{array}{l}\text { Thinking } \\
\text { vs. } \\
\text { Feeling }\end{array}$} & $-0.40(*)$ & $\begin{array}{l}\text { "Understanding of language and cultural practices of } \\
\text { local area" }\end{array}$ \\
\hline & $-0.38(*)$ & $\begin{array}{l}\text { "Communication to the external of the organization is } \\
\text { vital" }\end{array}$ \\
\hline & $-0.38(*)$ & "Project managers with excellent communication skills" \\
\hline & $-0.37(*)$ & $\begin{array}{l}\text { "Understanding and appreciation of cultural difference } \\
\text { involved" }\end{array}$ \\
\hline $\begin{array}{l}\text { J udging } \\
\text { Vs. } \\
\text { Perceiving }\end{array}$ & $+0.42(* *)$ & "National culture control communication process" \\
\hline
\end{tabular}

Thinkers decide things logically and objectively, while feelers use emotional appeals such as loyalty and responsibility. These concepts manifested weakly through the correlations of the general "Communication to the external of the organisation is vital", and project variables of "Understanding of language and cultural practices of local area", "Project managers with excellent communication skills" and "Understanding and appreciation of cultural difference involved". When the thinker decides that external communication is vital, the next logical step is to understand the cultural aspects involved and improve communication skills. Finally, the relationship between "J udging vs. perceiving" and the general "National culture control communication process" is positive, suggesting that people who are inclined to judge, since they desire organisation and control, would not conclude national culture to be a control factor hindering the communication process.

\section{Comparison Between Anglo Cluster and Far Eastern Cluster}

According to Trompenaars (1994), the Anglo and Far Eastern cultures have opposite cultural values, the Anglo culture being associated with individualism, specific relationships, universalism, emotional relationships and achievement. The Anglo respondents should therefore contain closer relationships between cultural variables and communication variables than the Far Eastern respondents. This turns out to be the case, with approximately $20 \%$ more significant correlations in the Anglo than the Far Eastern cluster results. It is noteworthy that the sign of the correlations for the two clusters is quite different, with $54 \%$ and $74 \%$ being positive for the Anglo and Far Eastern clusters respectively. These results could be due the "Face" barrier.

The number of significant correlations between the cultural and communication variables for the Anglo cluster are approximately double those of the Far Eastern cluster, when the comparisons are made individually between national, organisational culture and personal characteristics. It may be possible to conclude that organisational cultural dimensions would have more effects on communication than other variables.

\section{National Dimensions}

The dimensions of uncertainty avoidance, individual ism, power distance and masculinity broadly shape the aspects of the contents and style for each party in the communication process. Based on Hofstede's research, Hodgetts and Luthans (1993) identified different dimensions between Anglo and Far Eastern societies. Anglo societies are generally low power distance and individualistic, 
Table 5: Correlations between National Dimensions and Communication Variables

\begin{tabular}{|c|c|c|c|c|}
\hline \multirow{2}{*}{ Item } & \multicolumn{2}{|c|}{ Anglo Cluster } & \multicolumn{2}{|c|}{ Far Eastern Cluster } \\
\hline & $r$ & Communication & r & Communication \\
\hline $\begin{array}{l}\text { Uncertainty } \\
\text { Avoidance }\end{array}$ & $-0.45(*)$ & $\begin{array}{l}\text { "Understanding of language } \\
\text { and cultural practices of local } \\
\text { area" }\end{array}$ & $-0.49(*)$ & $\begin{array}{l}\text { "Understand the languages and } \\
\text { practices of the local culture } \\
\text { enhances communication" }\end{array}$ \\
\hline \multirow{4}{*}{$\begin{array}{l}\text { Individualism/ } \\
\text { Collectivism }\end{array}$} & $0.49(*)$ & $\begin{array}{l}\text { "Project managers have good } \\
\text { communication skills" }\end{array}$ & & \\
\hline & $0.43(*)$ & "Effective communication" & & \\
\hline & $-0.53(*)$ & $\begin{array}{l}\text { "National culture control } \\
\text { communication process" }\end{array}$ & & \\
\hline & $-0.47(*)$ & "Face" & & \\
\hline Power distance & $0.50(*)$ & "Lack of trust" & & \\
\hline $\begin{array}{l}\text { Masculinity/ } \\
\text { Femininity }\end{array}$ & $-0.45(*)$ & "Lack of personal skills" & $+0.50(*)$ & "Lack of motivation" \\
\hline
\end{tabular}

$* * p<0.01$ (2-tailed) $* p<0.05$ (2-tailed)

while Far Eastern societies are high power distance and collectivistic. Each requires a different approach to formulating an effective communication strategy.

Table 5 shows the significant correlations between national culture and communication variables for both the Anglo and Far Eastern clusters. Both Anglo and Far Eastern clusters are classified as low uncertainty avoidance societies. People in these societies tend to accept each day as it come, take risks rather easily and show a relatively greater tolerance for opinions and behaviours different from their own. Thus, they feel less threatened by the language and practices of different cultures when they communicate with others-as suggested by the correlations of both clusters on similar communication variables. From the Anglo (individualist) point of view, Far Eastern (collectivist) managers do not have good communication skills and are ineffective communicators. It may be that collectivism also helps to explain this finding. Collectivism stresses the importance of group decisions. When collectivists communicate with individualists, they would seem to be reluctant to make quick decisions and commit their organisation to these decisions. The Anglo cluster suggests that national culture controls the communication process. "Face" is an important barrier, when communicating with the Far Eastern cluster. This also explains the fewer number of significant relationships for the Far Eastern cluster. It is possible that praise is used more sparingly because this would involve singling out an individual and it may cause that individual to lose face.

Another manifestation of power distance is the willingness to trust other people. High power distance societies typically view others as a threat and, as a result, show less inclination to trust others. This is exhibited through the positive correlation of collectivism on lack of trust. When the Anglo cluster (Low power distance societies) communicated with Far Eastern cluster (High power distance societies), they felt that lack of trust hindered their communication process. Finally, the Anglo cluster (Masculinity societies) suggested that personal skills were among one of the communication barriers, which reflects their value of assertiveness and respect for the super-achiever. On the other hand, the Far Eastern cluster (also a masculinity society) indicates that motivation is not a communication barrier.

Organisational Dimensions

Culture control is increasingly used to replace rules-based control in an attempt to enhance communication within organisations. Table 6 shows the relationship between organisational dimensions and 
Table 6: Correlation between Organization Dimensions and Communication Variables

\begin{tabular}{|c|c|c|}
\hline Item & $r$ & Communication \\
\hline \multicolumn{3}{|l|}{ Anglo Cluster } \\
\hline \begin{tabular}{|l|} 
External vs. \\
Internal \\
emphasis
\end{tabular} & $-0.58(* *)$ & $\begin{array}{l}\text { "High levels of inter-personal and intra-personal skill are } \\
\text { required" }\end{array}$ \\
\hline \multirow[t]{8}{*}{$\begin{array}{l}\text { Task vs. Social } \\
\text { focus }\end{array}$} & $+0.62(* *)$ & $\begin{array}{l}\text { "Understanding of language and cultural practices of local } \\
\text { area" }\end{array}$ \\
\hline & $+0.61(* *)$ & "Two way communication both upward and downward" \\
\hline & $+0.61(* *)$ & $\begin{array}{l}\text { "Communication strategies to help minimize potential disputes } \\
\text { and misunderstanding" }\end{array}$ \\
\hline & $+0.56(* *)$ & "Effective communication" \\
\hline & $+0.51(*)$ & "Understanding and appreciation of cultural difference involved" \\
\hline & $-0.67(* *)$ & "Lack of trust" \\
\hline & $-0.61(* *)$ & "Resistance to change" \\
\hline & $-0.50(*)$ & $\begin{array}{l}\text { "Project type and duration has impact on communication } \\
\text { strategy and structure" }\end{array}$ \\
\hline \multirow{6}{*}{$\begin{array}{l}\text { Individuality } \\
\text { vs. Conformity }\end{array}$} & $+0.52(*)$ & "National culture control communication process" \\
\hline & $+0.46(*)$ & "Gender issues" \\
\hline & $+0.45(*)$ & "Lack of trust" \\
\hline & $-0.60(* *)$ & "Two way communication both upward and downward" \\
\hline & $-0.45(*)$ & "Staff communication is encouraged" \\
\hline & $-0.44(*)$ & "Effective communication" \\
\hline \multirow[t]{2}{*}{ Risk vs. Safety } & $-0.55(* *)$ & "Flexible form and style of communication" \\
\hline & $-0.46(*)$ & $\begin{array}{l}\text { "Project type and duration has impact on communication } \\
\text { strategy and structure" }\end{array}$ \\
\hline \multirow{5}{*}{$\begin{array}{l}\text { Adhockery vs. } \\
\text { Planning }\end{array}$} & $+0.59(* *)$ & "Communication is important" \\
\hline & $+0.49(*)$ & $\begin{array}{l}\text { "Understand the languages and practices of the local culture } \\
\text { enhances communication" }\end{array}$ \\
\hline & $+0.47(*)$ & "Communication planning" \\
\hline & $+0.46(*)$ & "Well established organizational culture and objectives" \\
\hline & $+0.44(*)$ & $\begin{array}{l}\text { "Knowledge of different cultures involve in the project is } \\
\text { important" }\end{array}$ \\
\hline \multicolumn{3}{|c|}{ Far Eastern Cluster } \\
\hline \multicolumn{3}{|l|}{$\begin{array}{l}\text { External vs. } \\
\text { Internal } \\
\text { emphasis }\end{array}$} \\
\hline \multirow{5}{*}{$\begin{array}{l}\text { Task vs. } \\
\text { Social focus }\end{array}$} & $+0.61(* *)$ & "High levels interpersonal/intra-personal skill management" \\
\hline & $+0.60(* *)$ & "Understanding and appreciation of cultural difference involved" \\
\hline & $+0.60(* *)$ & "Religious issues" \\
\hline & $+0.57(*)$ & "Face" \\
\hline & $+0.41(*)$ & "Awareness of national culture" \\
\hline \multicolumn{3}{|c|}{\begin{tabular}{l|l|l} 
Individuality & & \\
vs. Conformity & & \\
\end{tabular}} \\
\hline Risk vs. Safety & $+0.65(* *)$ & "Time limitation" \\
\hline \multirow{5}{*}{$\begin{array}{l}\text { Adhockery vs. } \\
\text { Planning }\end{array}$} & $+0.80(* *)$ & "Well established organizational culture and objectives" \\
\hline & $+0.72(* *)$ & "Awareness of national culture" \\
\hline & $+0.64(* *)$ & "Understanding and appreciation of cultural difference involved" \\
\hline & $+0.58(*)$ & "Face" \\
\hline & $+0.48(*)$ & $\begin{array}{l}\text { "Understanding of language and cultural practices of local } \\
\text { area" }\end{array}$ \\
\hline
\end{tabular}

** $p<0.01$ (2-tailed) $* p<0.05$ (2-tailed) 
communication variables both for the Anglo and Far Eastern clusters. An organisation emphasizing an external orientation places special emphasis on satisfying clients and customers. This can be taken to mean that external Anglo organisations require their personnel to have high inter-personal and intra-personal skills to communicate with clients or customers. Both clusters indicate that cultural variables and structured communication networks contribute towards effective communication. Interestingly, the Far Eastern cluster does not find "Religious issues" and "Face" to be significant communication barriers. This may be due to their being task-oriented and with their priorities focused on the organisational activities rather than concern for the individual and social needs of its members.

Firms that encourage individuality displayed an appreciation of diversity among their members, allowing greater latitude in member lifestyles and behaviours. This would seem to be consistent with the positive relationship from correlations for the first three Individuality vs. Conformity variables ( $r=0.52,0.46$ and 0.45 ), although the last three variables ( $r=0.60,-0.45$ and -0.44$)$ indicate that two-way communication would increase communication effectiveness.

An organisation's response to risk is an important dimension of organisational culture, particularly in a fluid and rapidly changing environment. Thus in a risk averse culture, they tend to encourage flexible form and style of communication for different projects, as indicated by the Risk vs. Safety variables $(-0.55,-0.46$ and 0.65$)$. Some organisations create adhockery responses to all changes, while other may opt for elaborate plans that anticipate most future scenarios. These were indicated through the positive correlations of the Adhockery vs. Planning variables for both Anglo and Far Eastern clusters, suggesting that, in an adhockery culture, cultural variables, organisational objectives and communication planning are not the most important issues in the communication process.

\section{Personal Dimensions}

Research in social psychology suggests that personality dimensions significantly affect the effectiveness and outcome of communication. Lachman (1983; 1988) tried to reconcile these different perspectives by showing that early and late socialization induce changes in different categories of values. Early socialization affects core values, and late socialization affects only periphery values. Thus, people's periphery values may change because of pressure to comply with organisational requirements and managerial policies, whereas their core values will not. When organisational role requirements are incongruent with core values, people tend to modify these role requirements.

The behaviour of individuals in the organisation is influenced by the values and beliefs the individuals bring with them to the their jobs. Since communication takes place between individuals, these differences in values and beliefs are manifested through their communication interactions. These different values and beliefs could assist or hinder the individual's ability to communicate with other. Table 7 shows the relationship between personal dimensions and communication variables.

Extroverts would be expected to like socializing and social engagement. Their orientation would be toward the outer world of people and things. Introverts, on other hand, are likely draw more to their own inner world of ideas. The survey supports this through the positive correlations of the Introversion vs. Extroversion variables. This suggests that introverts would withdraw to their inner world. They would not appreciate the benefits from cultural variables, twoway communication or inter/intra-personal skills in enhancing the communication process. Extroverts, on the other hand, would prefer the interaction communication from people of different cultures, which could improve their inter/intra-personal skills.

Sensing types are expected to show a marked preference for facts and seek out detail while intuitive types are likely to prefer to focus on the big picture. These preferences would explain the negative correlations of the Sensing vs. Intuition variables for the Anglo cluster, which suggested that managers (Sensing types) would endorsed a communication strategy to help minimise potential disputes and misunderstanding, although this would involve the managers understanding and appreciating cultural differences. Furthermore, the correlations for the Far Eastern managers indicate that limited resources and varying capacity and capability would hinder the communication strategy. 
Table 7: Correlation between Personal Dimensions and Communication Variables

\begin{tabular}{|c|c|c|c|c|}
\hline \multirow{2}{*}{ Item } & \multicolumn{2}{|c|}{ Anglo Cluster } & \multicolumn{2}{|c|}{ Far Eastern Cluster } \\
\hline & $r$ & Communication & $r$ & Communication \\
\hline \multirow{3}{*}{$\begin{array}{l}\text { Introversion } \\
\text { vs. } \\
\text { Extroversion }\end{array}$} & $+0.56(* *)$ & $\begin{array}{l}\text { "High levels of inter-personal and } \\
\text { intra- personal skill are required" }\end{array}$ & \multirow{2}{*}{$+0.51(*)$} & \multirow{2}{*}{$\begin{array}{l}\text { "Two way communication both } \\
\text { upward and downward" }\end{array}$} \\
\hline & $+0.52(*)$ & $\begin{array}{l}\text { "Project managers with excellent } \\
\text { communication skills" }\end{array}$ & & \\
\hline & $+0.51(*)$ & $\begin{array}{l}\text { "Two way communication both } \\
\text { upward and downward" }\end{array}$ & $+0.51(*)$ & $\begin{array}{l}\text { "Understanding of language and } \\
\text { cultural practices of local area" }\end{array}$ \\
\hline \multirow{4}{*}{$\begin{array}{l}\text { Sensing } \\
\text { vs. } \\
\text { Intuition }\end{array}$} & $-0.53(*)$ & $\begin{array}{l}\text { "Understanding and appreciation of } \\
\text { cultural difference involved" }\end{array}$ & $-0.52(*)$ & "Limited resources" \\
\hline & $-0.52(*)$ & $\begin{array}{l}\text { "Communication strategies to help } \\
\text { minimize potential disputes and } \\
\text { misunderstanding" }\end{array}$ & $-0.48(*)$ & "Varying capacity and capability" \\
\hline & $-0.51(*)$ & $\begin{array}{l}\text { "Project managers with excellent } \\
\text { communication skills" }\end{array}$ & & \\
\hline & $-0.47(*)$ & $\begin{array}{l}\text { "Understanding of language and } \\
\text { cultural practices of local area" }\end{array}$ & & \\
\hline \multirow{3}{*}{$\begin{array}{l}\text { Thinking } \\
\text { vs. } \\
\text { Feeling }\end{array}$} & $+0.49(*)$ & $\begin{array}{l}\text { "Flexible form and style of } \\
\text { communication" }\end{array}$ & & \\
\hline & $-0.47(*)$ & "Effective reporting system" & & \\
\hline & $-0.45(*)$ & $\begin{array}{l}\text { "Two way communication both } \\
\text { upward and downward" }\end{array}$ & & \\
\hline \multirow{2}{*}{$\begin{array}{l}\text { J udging } \\
\text { vs. } \\
\text { Perceiving }\end{array}$} & $-0.60(* *)$ & $\begin{array}{l}\text { "National culture control } \\
\text { communication process" }\end{array}$ & & \\
\hline & $+0.58(* *)$ & "Lack of personal skills" & & \\
\hline
\end{tabular}

Thinkers are expected to decide things logically and objectively while feelers base their decisions on more subjective ground. These are manifested through the correlations of the thinking vs. feeling variables in the study, suggesting that thinking type managers believe that an effective reporting system and two way communication would enhance the communication process, while feeling type managers believe that flexible forms and styles of communication improve the communication process.

Finally, perceiving types are expected to be flexible in life, always seeking more information, with judgers tending to seek closure over open options together with a desire for control. These preferences would explain the positive correlations of the Judging vs. Perceiving variables for the Anglo cluster. The perceiving types recognized that national cultures control the communication process and that personal skills would hinder the communication process.

\section{SUMMARY ANDCONCLUSION}

This paper provides the results of a small survey of 36 Singapore managers aimed at identifying the main cultural and individual factors affecting project communication. The main findings that are suggested by the surveyare:

In terms of Hofstede's types of national cultures, respondents from a Low Uncertainty Avoidance culture appear to be associated with a communication process based on trust and one that is therefore less formal and standardized. In contrast, respondents from a High Uncertainty Avoidance culture have a more formal and standard communication process, such as in written communications. The results suggest that the communication process between those from Individualist and Collectivist societies can be difficult, perhaps because a Collectivist culture's approach is to take time to consult with, and receive the consent of, their group members. In addition, the message from those belonging to a Collectivist culture is 
often highly coded and implicit. Those belonging to an Individualist culture tend to view personal skills as a communication barrier, due to their nature in support of greater individual initiative. Finally, those belonging to a Masculinity culture may not view limited resources as a communication barrier, probably because individuals tend to be dominant with power so resources would not be beyond their control.

For organisational cultures, the more externally oriented organisations of the respondents seem to require higher levels of inter/intra-personal skills. In addition, these organisations are more likely to establish a communication strategy for cross-cultural interactions. The more task focused organisations, on the other hand, tend to place the demands of the job before the individual. Organisations may have to reduce their resistance to change if they wish to strike a balance between their activity and social orientation. Those belonging to a riskaverse culture may have higher level of ambiguity tolerance than those of a Safetyconscious culture, so that language is not viewed as a communication barrier. They may, however, perceive personal skills to be a barrier to communication. Finally, those from a Planning culture emphasise the need for structure and a non-ambiguous communication process, while those from an Adhockery culture may require an informal communication structure. Planning culture members may also have a greater recognition that cultural dimensions are important factors in the communication process.

From an individual perspective, the more extroverted respondents seem to be more competent in both the communication and cultural practices of their environment. This may be because they prefer the interactionoriented style of communication and the personal bond with their counterparts. In contrast, those more introverted seem to be more territorial and internally focused. The 'sensing' respondents tend to explore cultural differences to enhance their crosscultural communication process and prefer facts rather than the 'big picture'. Possibly due to the logical nature of thinkers, they are more likely to perceive cultural aspects and personal communication skills as the main tools for communicating with clients or customers. Finally, the judging type respondents may not perceive national culture to be a communication barrier, due to their desire for control and organisation.

The results of the research suggest that the managers' attitude and behaviours toward communication may be guided to large extent by their level of competence. The study also provides evidence to suggest that the individuals' understanding of the communication process and its barriers, the way they behave with other individuals and expect to be treated, varies according to national cultures. This suggests that organisations should have a balanced dual strategy, as advocated by Abell (1993) and supported by the research of Appelbaum et al. (1998), which is to encourage managers to think globally and act locally. To accomplish this change management process, organisations would need to formally develop key behavioural skills and individual competencies to deal with conflict, culture and change.

\section{REFERENCES}

Abell, D.F. (1993) Managing with Dual Strategies-Mastering the Present, Preempting the Future, Free Press, New York.

Adler, N.J . (ed.) (1997) International Dimensions of Organisational Behavior, Southwestern, Cincinnati , $\mathrm{OH}$.

Appelbaum, S.H., Shapiro, B. and Elbaz, D. (1998) The Management of Multicultural Group Conflict, Team Performance Management, 4 (5), 221-34.

Buxey, G. (2000) Strategies in an Era of Global Competition. International J ournal of Operations and Production Management, 20 (9), 997-1016.

Cartwright, S. and Cooper, C.L. (1993) The Role of Culture Compatibility in Successful Organisational Marriage. Academy of Management Executive, 7, 57-70.

Cartwright, S. and Cooper, C.L. (1996) Managing Mergers, Acquisitions and Strategic Alliances: Integrating People and Cultures, Butterworth-Heinemann, Oxford.

Chow, C.W., Shields, M.D. and Chan, Y.K. (1991) The Effects of Management Controls and National Culture on Manufacturing: an Empirical Investigation. Accounting, Organisations and Society, 209-334. 
Edwards, R.W., O'Reilley, H. and Schuwalaw, P. (1997) Global; Personnel Skills: A Dilemma for the Karpin Committee and others, Monash University, Faculty of Business and Economics: Melbourne.

Granell, E. (2000) Culture and Globalisation: a Latin American Challenge. Industrial and Commercial Training, 32 (3), 89-93.

Hall, E. (1959) The Silent Language, Doubleday, Garden City, NY.

Hall, E.T. and Hall, E. (1994a) How Cultures Collide, Ginn Press, Needham Heights.

Hall, E.T. and Hall, M. (1994b) Understanding Cultural Differences: Key to Success in West Germany, France and the United States, Intercultural Press Incorporated, New York.

Harris, H. and Kumra, S. (2000) International Manager Development-Cross-cultural training in highly diverse environments, The Journal of Management Development, 19 (7), 602-14.

Hodgetts, R.M. and Luthans, F. (1993) 'U.S. multinational' Compensation strategies for local management. Compensation and Benefits Review, March-April, 42-48.

Hofstede, G. (1980) Culture's Consequences: International Differences in Work-Related Values, Sage Publications, Beverly Hills.

Hofstede, G. (1991) Cultures and Organisations: Software of the Mind, McGraw-Hill, New York.

Kolde, E. J . (1982) The Environment of International Business: A critical review of concepts and definitions, Kent Publishing Co., Boston.

Lachman, R. (1983) Modernity change of core and periphery values of factory workers. Human Relations, 36 (6), 563-80.

Lachman, R. (1988) Factors influencing workers. Organisation Studies, 99, 487-510.

Laurent, A. (1983) The Cultural Diversity of Western Conceptions of Management. International Studies of Management and Organisation, Spring-Summer, 75-96.

Loosemore M, and Al MusImani H.S. (1999) Construction project management in the Persian Gulf: intercultural communication. International Journal of Project Management 17 (2), 95-100.
Numeroff, R.A. and Abrams, M.N. (1998) Integrating Corporate Culture from International M\&As. HR Focus, J une, 12.

Olie, R. (1994) Shades of culture and institutions in international mergers. Organisation Studies, 15 (3), 381-405.

Oudenhoven, J.P.V. and Boer, T.D. (1995) Complementarily and similarity of partners in international mergers. Basic and Applied Social Psychology, 17, 343-56.

Padgett, V.R. and Wolosin, R.J . (1980) Cognitive similarly in communication. Journal of Personality and Social Psychology, 39 (4), 654-59.

Ralston, D. (1993) Differences in managerial values: A study of US, Hong Kong and PRC managers. Journal of Business Studies, 24 (2), 249-75.

Ronen, S. and Shenkar, O. (1985) Clustering Countries on Attitudinal Dimensions: A Review and Synthesis. Academy of Manage ment J ournal, September, 435-54.

Runkel, P.J. (1956) Cognitive similarity in communication. Sociometry, 19 (3), 178-87.

Schein, E. (1992) Organisational Culture and Leadership, J ossey Bass, San Francisco.

Sprinks, B. and Wells, N. (ed.) (1994) Organisational Communication: $A$ Strategic Approach, Dame Publications, Houston, TX

Trompenaars, F. (ed.) (1994) Riding the Waves of Culture, Irwin, New York.

Trompenaars, F. and Hampden-Turner, C. (ed.) 1998, Riding the Waves of Culture: Understanding Diversity in Global Business, McGraw-Hill, New York. 